Tuttennout, M. van, Haygourt, P., \& Brown, C.M. \{1997\}. Electrophysiological evidence on the time course of setnantic and phonological processes in speech production. Jounual of Experisental Pyctiology: Leanting, Menroy, and Cogetition, 23, 787-806.

Vandenberghe, R.,e.a. (x996). Functiond anaconyy of a contmon semantic system for words and picrures. Nazitur, 383, 254-256.

Villafura, T. $(1992)$. Physics and insrrumentation: Magnetic resonance imaging. In: S.H. Lee, C.Y.G. Rao, \& R.A. Zimmerman (red), Cranial MRI and Cr. New York: MCGraw-Hill.

Aanbevolen literaturar

Bear, M.F., Connors, B.W., \& Paradiso, M.A. (1996). Neuroscience Exploring the brain. Baltimore: Wiltiams \& Wilkins

Gazzaniga, M.S. (red.\} \{1995). The cognitive netrosciences. Cambridge, MA: M1T Press.

Hagoorr, P., \& Brown, C.M. [1993). Hersenpotentialen als mat voor het menselijk

taalvermogen. Stent, Sproak- ot Tarlpatlologie, z, z13-235.

Hagoort, P., \& Brown , C.M. (red.) (1998). The Iletrocognition of langtage processing, Oxford: Oxford University Press.

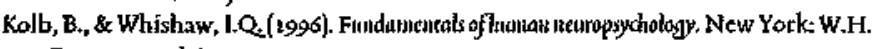
Freeman and Company.

Posner, M.I., \& Raichle, M.E. (1994). Inerges of Mind. New York: Scientific Americain Library.

\section{A2.3 \\ De neurale architectuur van het menselijk taalvermogen}

P. HAG OORT

M2x Pfauck Instituut voor Psycholingulstick, Nijinegen

\section{P. INDEFREY}

Max Planck Lastittut voor Paychofinguîstiek, Nümegen

$2 \quad$ Het menselijk brein

2.1 Taalgebieden in het brein

3 Onderzoeksmethoden

3.1 De laesiemethode

3.2 De elektrofysiologische methode (ERPS)

3.3 Magneto-cncefalografic (MEG)

3.4 Maten getelateerd aan de metabole hersenacriviteit

3.5 Coregistratie van hersenactiviteit

4 De neurale architecruur van caalfuncries

4.1 De neurale architectuur van woordverwerking

4.2 De neurale architecturar van zinsverwerking

4.3 De rol van de rechter hersentelit

REDACTIE: dr.H.F.M. Perers, hoofdredactear | prof. dr. R. Bastiuanse | prof. dr. J. vau Borsel | prof. de. P.H.O. Dejonckete | drs. K. Jansonius-Schultheiss | drs. Sj. vant der Meulen | B.J.E. Mondelaers

STEM-SPRAAK-TAALPATHOLOGIE AFE. 3 (1997) 


\title{
De neurale architectuur van het menselijk taalvermogen
}

\author{
P. HAGOORT \& F. INDEFREY
}

\section{$1 \quad$ Jaleiding}

Geen enkele andere diersoorr dan de mens beschikt over het vermogen tot communicatie via cen eindig aantal symbolen en combinarieregeis die samen een oneindig aantal boodschappen mogetijk maken. Het spreken van en luisteren naar een vorm van taal is in de evolutionaire geschiedenis volgens de huidige schatringen ontstaan ergens tussen het verschijnen van homo habilis, zo'n twee miljoen jaar geleden en homo sapiens, zo'n honderdduizend jaar geleden. In tegenstelling tot spreken en luisteren zijn şchrijven en lezen zeer recent verworven vaardigheden. Het alfabetische schrift is ongeveer drie tot vier duizend jaar oud, niet veel meer dan een milliseconde op detevolutionaire rijdschaal. Deze taalvaardigheden moeten expliciet aangeleerd worden. Spreken en luisteren worden daarencegen in de eerste jaren van het leven spelenderwijs verworven, en zijn in de loop van de evolutionaire geschiedenis vast in het brein verankerd.

Spreken, laisteren, lezen en schrijven zijn elk op zich complexe cognirieve vaardigheden waaraan verschillende deelcomponenten zijn te onderscheiden. Zo moet voor elk van deze vaardigheden woordkennis uit her langetermijngeheugen wozden opgehaald. Deze woordkennis beheist mininaal de vorm van een woord (her klank- of schriftbeeld), de grammaticale eigenschappen (zelfstandig naamwoord, werkwoord; onzijdig, mannelijk/vrouwelijk) en de betckenis. Daarnaast moet de raalgebruiker uit het langeternijngeheugen de ketnis ophalen dic hem in staat stelt de afzonderlijke woorden in grotere eenheden, zoals zinnen, samen te sineden. Doorgaans worden deze afzonderlijke brokjes talkennis viijwel moeiteloos in tienden van seconden geactiveerd en met elkaar gecombineerd. De snelheid warnee deze processen zich afspelen 
is ronduit verbluffend. Zo kunnen we per seconde 25 spraakklanken herkennen, terwijl we van nict-talige geluiden er hoogstens zo'n negen per seconde kunnen identificeren (Liberman \& Matringly, 1989). Spreken doen we met een snclheid van zo'n drie woorden per seconde, waarbij niet alleen de relcvante woordkennis uit her geheugen moer worden opgehaald, maar ook nog eens een groot azntal spicren op een gecoördineerde wijze worden aangestuurd on de woorden uit re spreken.

Voor clk van de genoernde taalvaardigheden bestaan uitgewerkte modellen van de daarbij betrokken ketnisrepresentakies en ophaalprocessen. Dir samenstel van deekomponenten wordt wel de cognitieve architecruur van het menselijk taalvernogen genoend.

Hoewel inmiddels de nodige vorderingen zijn gemaakt bij het ontwerpen van computerprogranma's die aspecten van het menselijk taalvermogen lijken te imiteren, is tor op heden ber menselijk brein nog steeds het enige medium dat taalgedrag in zijn volle conplexireit mogelijk maakt. Om een volledig beeld te krijgen van de mens als taalgebruiker is het dan ook van belang te specificeren hoe taal in het brein verankerd is. Naast een specificaric van de cognitieve architectuut van verschillende taalfuncties, is dus kennis nodig over de daarmee corresponderende neurale architectume. Het doet van dit hootdstuk is in grote lijnen een schers te geven van de neurale architectuur van het menselijk rantvermogen, voorzover darover iets bekend is. Teneinde deze samenvattende schets te kunnen geven, zullen we eersi de daartoe noodzakelijke achrergrondinformatie over de menselijke hersenen en de relevante onderzoeksmethoden bespreken.

Het menselijk brein

De hersenen zijn her meest complexe orgaan van het menselijk lichaam. In een ruimte ter grootce van ecn halve voctbal bevindt zich een microkosmos van meer dan honderd miljard zenuweellen. Elk van die honderd niljard zenuwcellen (neuronen) heeft vele verbindingen met andere zenuwcellen, sorns wel vijfrienduizend.

De complexe structuur van ons brein heeft zich in de evolurionaire geschicdenis ontwikkeld vanuit het cenerale zenuwstelsel van cerdere, verwante sootten. Het bouwplan van her centrale zenuwstelsel bij de mens vertoont dan ook grote overeenkonsten mer dar van andere zoogdiesen. Ook bij andere zoogdicren kunnen we twee hersenhelften onderscheiden, en zijn kleine hersenen (cerebelltmi) anowezig. Evencens treffen we bij andere zoogdieren een hersen- 
stam en een ruggenmerg aan die qua bouw en functie grote overeenkomsten vertonen met her cenrrale zenuwstelsel van de mens. Maar daarnaast zijn ex cok opvallende verschillen.

Wat onmiddellijk opvalt aan de menselijke hersenen in vergelijking met de hersenen van andere zoogdieren, is de roename in het aantal windingen dat aan de oppervlakre van de menselijke grote hersenen (cerebrum) zichtbaar is. Deze toename hangt samen met de toegenomen gtootte van de neocortex bij de mens, die ongeveer tachtig procent van ons brein uitmaakt. De neocortex is het 1,5 tot $3 \mathrm{~mm}$ dunne laagje zenuwcellen dat zich grotendeels aan de buitenkant van de grote hersenen bevindt. Deze heeft bij de mens cen oppervlakre bereikt van regen de 2,5 vietkante meter. Om die tijdens de evolutie toegenomen laag in de schedel onder te kunnen brengen is de cortex als een stuk verftommeld papier binnen ons schedeldak opgevouwen. De groeven die in de oppervlakte van het cerebrum zichtbaar zijn worden sulci (enkelvoud: sulcus) genoemd, de gedeelten die aan het oppervlak zelf zichrbaar zijn, staan bekend als gyri (enkelvoud: gyrus\}. Waar we precies de sulci en gyri kunnen vinden kan enigszins verschillend zijn tussen de linker en de rechter hersenhelft. Van individu tot individu kunnen de verschillen in plaats, omvang en exacte structuur van de gyri en sulci veel anzienlijker zijn.

We kunnen elke hersenhelft onderverdelen in een viertal kwabben: de frontaalkwab, de pariëraalkwab, de remporaalkwab (ook wel slaapkwab genoemd) en de accipitaalkwab (figuur $\mathbf{x}$ ).

Elk van deze kwabben is van belang voor vele cognitieve funcries, maar heeft tevens eca eigen zwarrepunt in her geheel yan onze cognitieve huishouding. Zo is de occipitaalkwab onontberlijk voor visuele waarneming, de temporaalkwab voor auditieve waaneming, en is de bijdrage van de frontaalkwab essentieel voor ons bewegingsapparaat. De parižtaalkwab ten slotte is cruciaal voor de verwerking van somatosensorische informatie. Binnen iedere kwab is een aantal gyti te onderscheiden. De tempotaalkwab heeft bijvoorbeeld een drietal gyri: een bovenste, een middelste en onderste temporaalgyrus. Een complicerende factor voor niet-anatomen is overigens dat de benoeming van gebieden binnen een kwab niet altijd eenduidig is. Dit is met name het geval voor de fromtaal kwab.

Behalve het in kaate brengen van her breinlandschap op basis van uirerlijk zichtbare kenmerken, zoals het verloop van sulci en gyri, zijn ook andere hersenkarteringsmethoden in zwang. Een van die methoden baseert zich op de 


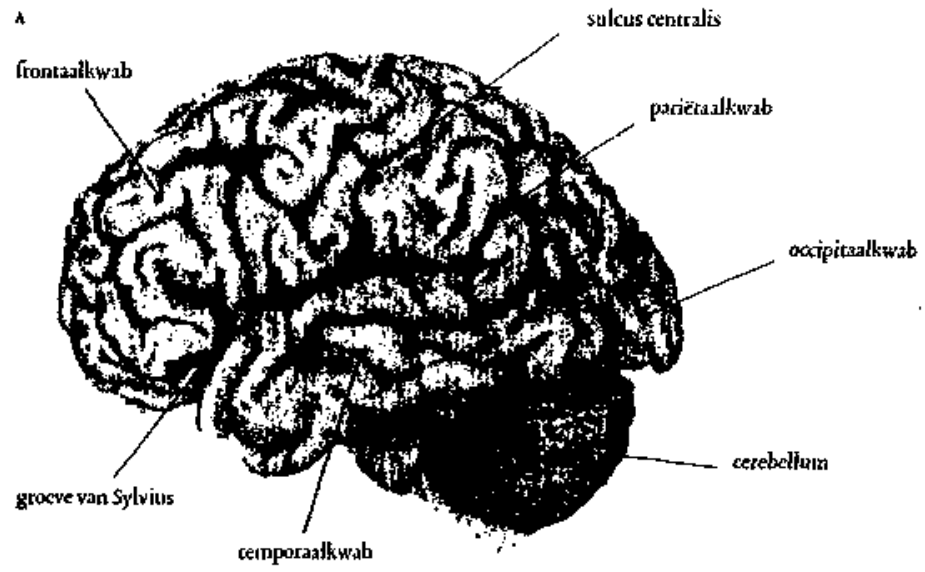

8

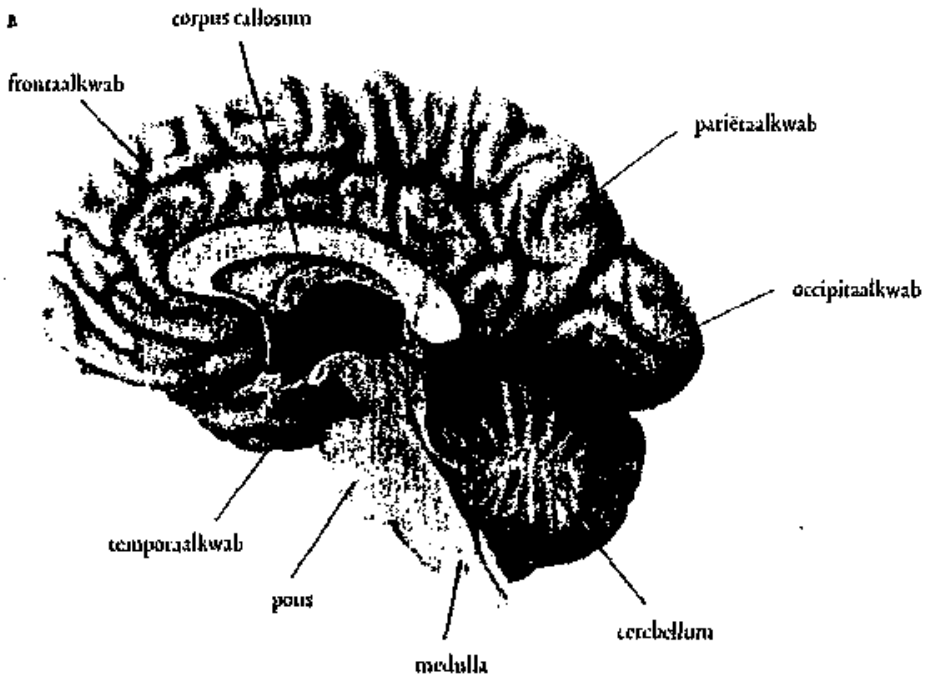

Figutur a I. De lacatic van de vier kwabben, het cerebellum en de twee betangrijkste grocven op een zijjanzzicht vau de linker hersenhelfí ( $A$; cen mediaul aanzicht van de hersenen ter hoogtc van lier corpus callostan, de verbindingsbalk aussen de bejde hersenheiften (B) 
structuur van de zenuwcellen die zich in de cortex bevinden. Het algemenc bouwplan van alle neuronen is gelijk (figuur 2).

Zenuwcellen bestaan uir een cellichaam en een wisselend aantal uirlopers (dendrieten) voor het ontvangen van signalen, en fén uitloper (het axon) voor de voortgeleiding van signalen naar andere neuronen. Her signaal van een neuron is een korrdurende, lokale voltageverandering cussen de binnen- en buirenkanc van de celmembraan. Bij overschrijding van een drempelwaarde resulteert deze voltageverandering in een actiepotentiaal die zich mer een snelheid van een tot honderd meter per seconde langs het axon voortbeweegt.

De signazloverdracht russen twee zenuwcellen vindt plaats aan de synaptische viteinden, waar de actiepotentiaal tot het vrijkomen van chemische stoffen (neurotransmitters) leide. Dit proces bewerkstelligt cen vexandering van de membraanpotentiaal van de zenuwcel aan de ovetzijde van de synaptische spleet Afhankelijk van de richting van deze potentiaalverandering onderscheiden we inhiberende synapsen en excirerende synapsen. Inhiberende synapsen verminderen het activatienivcau van de ontvangende zenuwcel, exciterende synapsen verhogen het activatieniveau.

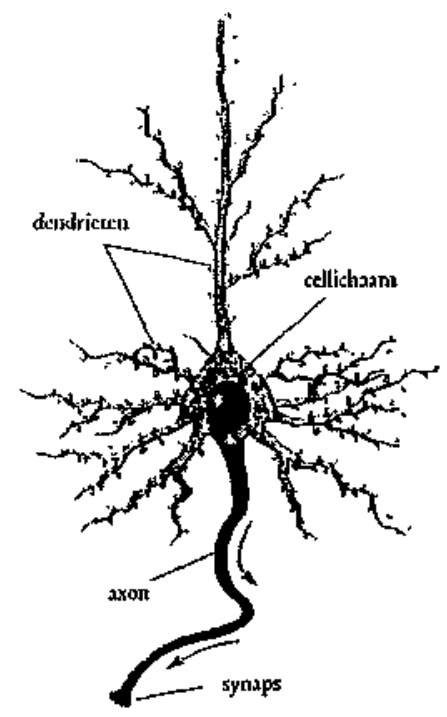

Figutur z | Het algemene bouwplan van een zentwcel (nearon]. geill lustreerd voor een piranidecel. 
Hoewd het bouwplan van alle netronen in principe gelijk is, hebben toch geen twee neuronen precies dezelfde vorm. Op basis van verschillen in structruurkenmerken (zoals de dendrietboom) kunnell we een hele reeks verschillende typen neuronen onderscheiden. Op basis van een analyse van de aanwezige celrypen (cyroarchitectonica) kunnen we hersengebieden van elkaar onderscheiden. Op deze wijze ontstar een cytoarchitectonische kaart van de cortex. Het meest bekende voorbeeld daarvan is de Btodmannkaart (zie figuur 3), vernoemd naar de anatoom Korbinian Brodmann (1868-1918) die als een van de eersten hersengebieden indeelde op basis van celstructuren. In de Brodnannkaart is etk afzonderlijk gebied van een nummer voorzien. De primaire motorschors is bijvoorbeeld Brodmanngebied 4 , de primaire visuele schors Brodmanngebied 17. Deze nummers hebben geen spectale betekenis anders dan dat ze dc volgorde aangeven waarin Brodmann zich door het brein heenwerkte.
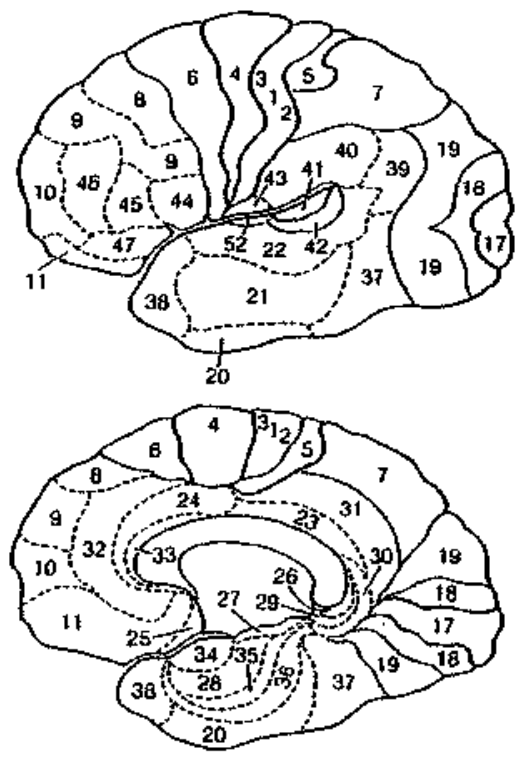

Figutur 3 | Brodmonngebieden. Sommige gebieden hebben histologisch scherpe grenzen (doóggerrokken dikke lijnen), andere gebieden, zoals 6 en 18-19, hebben minder scherp afgebakendt histologische grenzen (doorgetrokken dunne lijnen). De overbijvende gebieden lubben geen sclucrpe grenzen maar gaan geleidelijk in clkans over (onderbroken lijneu) (naar Kolb \& Wishaw, 1996). 
Hoewel we vandaag de dag weten dat de grenzen van de cytoarchitectonische gebieden veel vager zijn en van individu tot individu veel sterker verschillen dan wordt gesuggereerd door de Brodmannkaart, is de indeling van Brodmann desalnietrernin nog steeds cen onmisbaar communicatiemiddel onder neurowetenschappers voof dè identificatie van verschillende hersengebieden.

\subsection{TAALGEBIEDEN IN HET BREIN}

Van oudsher zijn er twee gebieden in de linker hersenhelft te onderscheiden waarvan bekend is dat ze een belangrijke rol spelen bij het menselijk taalvermogen. Deze zijn het gebied van Broca en het gebied van Wernicke. Her gebied van Broca ligt in de frontalkwab, aan de voorzijde van de groeve van Sylvius. Het gebied van Wernicke ligt in de temporaalkwab aan de achterzijde van deze zelfde groeve. Voor beide gebieden geldt dat de precieze atgrenzing van andere hersengebieden niet zonder problemen is, en dar met name voor het gebied van Wernicke geen eensluidendheid bestaat over de exacte plaats. Met die kantrekening kunnen we het volgende zeggen: het gebied van Broca bevindt zich in de onderste gyrus van de frontaal kwab. Het grenst aan de achrezzijde (caudaal) aan de primaire motorische schors en omyar de Brodmanngebieden 44 (de pars opercularis) en 45 (de pars triangularis). Het gebied van Wemicke bevindt zich in de bovenste temporaalgyrus en grenst aan de achterzijde (caudaal) van de auditieve cortex. Het omvat onder andere het achterste gedcelte van Brodmanngebied 22.

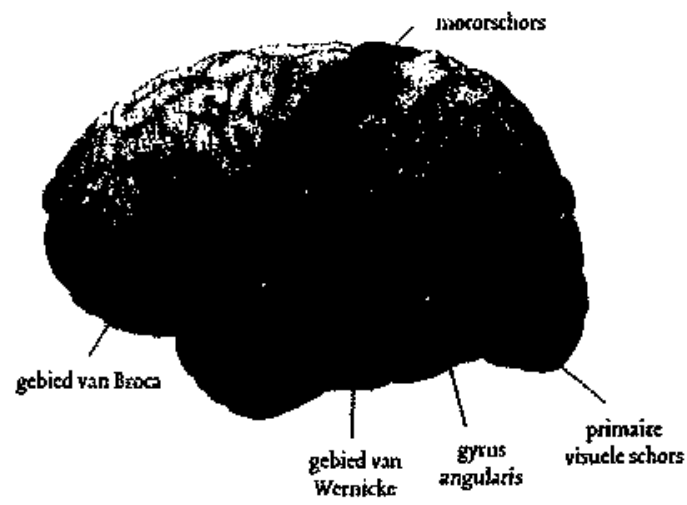

Figuut 4 | Het kiassicke neurale archircectuuttrodel van tal, gebaseerd op Geschwinds weergave van Wernickes model (naar Geschwind, 1979). 
Behalve het gebied van Broca en her gebied van Wernicke zijn or twee andere gebicden dic vaak in samenhang met taalfuncties genoend worden. Dit zijn de gyrus angularis (Brodmanngebied 39) en de gyrus supramarginalis [Brotmanngebied 4o). Beide gebieden liggen in het achterste gedeelte van de pariëtaalkwab. De gyrus angularis vormt het drielandenpunt tussen de occipitaalkwab, de remporaalkwab en de pariëtaalkwab. Het grenst aan de bovenzijde (dorsaal) van her gebied van Wernicke. In het klassieke Wernicke-Geschwindnodel (Geschwind, 1979, figuur 4) wordt aan deze gyrus een centrale rol tọebedeeld bij het onzetten van het visuele woordbeeld dat is opgebouwd op basis van de visuele informatie uit de occipitaalkwab, in het bij een woord behorende klankpatroon. Daartoe zou de visuele informatie via de gyrus angularis moeten worden doorgeschakeld naar het in de angrenzende temporaalkwab gelegen gebied van Wernicke. De gyrus supramarginalis ten sloute grensc aan de voorzijde (rostraal) van de gyrus angularis.

War de precieze bijdrage van deze gebieden is aan de menselijke taalfuncties zullen we Jater bespreken. Allereerst besteden wij nu aandacht san methoden om de bijdkagen van hersengebieden aan verschillende aspecten van het menselijk taalvermogen op het spoor re komen.

\section{Ondcrzocksmethoden}

Voor cogniticve functics als het waarnemen van objecten, geheugen, motoriek enzovoort geldt dar deze ook bij primaten en andere zoogdieren op vergelijkbare wijze als bij de mens worden aangetroffen. Traditionecl heefr dierexperimentecl onderzock veel kennis opgeleverd over de organisatie van deze functies in her brcin van hogere diersoorten. De overeenkomst in hersenstructuren cussen de mens en primaren rechrvasurdige de verwachting dar deze functies op soortgelijke wijze in her menselijk brein gerealiseerd zijn. Inmiddels heeft onderzock met moderne hersenscanningstechnieken bevestigd dat deze aanname door de bauk genomen juist is.

In tegenstelling tor de meeste andere evolutionair en neuraal verankerde cognicieve functies zijn geen dicrmodellen beschikbaar voor de taalfuncties. Ook al vindt conmunicatie plaats tussen leden van andere diersoorten, algemeen wordt anngenomen dat in die gevallen het communicariemedium zodanig in aard on kraclat verschilt van mensentalen dat gencralisaties van dierstudies naar het menselijk taalsysteem zeer beperkt of onmogelijk zijin.

Tor voor kort was onze kennis over taal en hersenen dan ook volledig afkomseig van patiënten met een hersenbeschadiging. Experimenten van de natuur zelf in de vorm van bijvoorbeeld een hersenberocrte kunnen resulteren 
in uitval van taalfuncties. Door de aard van de taaluitval te corteleren thet de plats en de omvang van de hersenlaesie kan informatie verkregen worden over de voor taalfuncties relevante hersengebieden. Deze hersenlaesiemethode wordt al meer dan honderd jaar gebruikt. De laatste vijftien jaar heeft de ontwikkeling van nieuwe hersenscanningstechnieken ertoe geleid dar her tegenwoordig mogelijk is onder experimenteel berer gecontroleerde condiries de met taalfuncties samenhangende hersenactiviteit te registreren. In het onderstaande zullen we in kort bestek het scala aan technieken dat ons thans ter beschikking staat bij het onderzoek naar taal en hersenen de revue laren passeren (voor een meer gedetailleerde behandeling zie hoofdstuk A9.5).

\subsection{DE LAESTEMETHODE}

Een hersenbeschadiging in de vorm van bijvoorbeeld een cerebrovasculair accident ( $\mathrm{CVA}$ ) leidt tot afsreiving van hersenweefsel (necrosis) op die plaatsen wasr de zuursroftoevoer ren gevolge van her cva tijdelijk heefr stilgelegen. De resulterende structurele beschadiging van het hersenweefsel is zichtbaar te maken op een CT-scan of cen MRl-scan. Tevens kan met behulp van gestandaardiseerde neuropsychologische rests en via meer specifiek onderzoek nar cognitieve functies inzicht verkregen worden in de cognitieve uitval die met de laesie gepaard gant. Door de laesiegegevens te paren aan de uitvalssymptomen wordt vervolgens getracht de functie die het beschadigde weefsel in het gezonde brein heeft vast te stellen. Vooral bij laesies van bepętkte omvang (focale laesies) en goed afgebakende uitvalssymptomen is op deze wijze relevante informatie verkregen over de bijdrage van verschillende hersengebieden aan cen hele teeks van cognitieve functies.

Met betrekking tot het menselijk taalvernogen is met behulp van de laesiemethode vastgesteld dat bij overwegend rechtshandige personen de liaker hersenhelft een cruciale rol speelt. Meer specifiek zijn het binnen deze hemisfeer de frontale en remporale hersengebieden die grenzen aan de groeve van Sylvius (de perisylvische gebieden) die onontbeerlijk zijn voor het produceren en begrïpen van taal. Een beschadiging van deze gebieden leidt doorgaans dan ook tot meer of minder ernstige taalstoornissen.

Lastiger wordt het wanneer we op basis van laesiestudies een nadere functionele precisering zouden willen geven van de rol van de verschillende perisylvische hersengebieden. Indien we bijvoorbeeld een schets willen gevenyan de perisylvische gebieden die van speciaal belang zijn voor het aanbrengen van een grammatical correcte structuur bij ralproductie en het gebraiken van syntactische informarie bij het begrijpen van taal, dan is dar nier goed te doen 
op basis van de thans beschikbare lacsiestudies. De resulearen verschillen te zeer om een eensluidende conclusie toe te sraan. in mindere mate geldr herzelfde voor andere taslaspecten, bijvoorbeeld met berrekking tot de voor woordbetekenis cn woordklank crucinle hersenstructuren.

Er is een aantal redenen warom laesiestudies alleen onvoldoende zijn en aanvulling behoeven van andere hersenscanningsmethoden. Allereerst geeft een CT-scan of MRi-scan geen volledig beeld van de gebieden die door de besie minder cffectief functioneren. Op basis van de scans kunnen de gebieden mer aangetast weefsel worden geïdentificeerd. In de hersenen zijn vele gebieden echter via vezclbanen met clkaar verbonden. Dientengevolge kan een structurele beschadiging op cen bepaalde plants in het brein consequenties hebben voor het functioneten van andere gebieden die mer de beschadigde gebieden in verbinding staan. Van een CT-scan of MRI-scan kan niet worden afgelezen welke intacte gebieden in hun funcrioneren worden belenmerd door de structurele beschadiging. Deze informatie kan wel worden verkregen mer behulp wan regisrraries die het met hersenacrivireit samenhangende celmetabolisme of de daraan gerelateerde bloedtoevoer meren, zoals in PET of fMRT.

Een tweede problecm is dat hersenbeschadigingen zich niet netjes trouden aan de grenzen van funcrioneel onderscheiden hersengebieden. De precieze begrenzing van laesies ten gevolge van cen cva hange mer name samen mex de vascularisatie van her brein. De wijze warop bloedvaten in de hersenen vertakt zijn is ecluer nier eenduidig gerelareerd aan de functionele onderverdeling van hersengebieden. Bij elk door cen Cva getroffen persoon is $d c$ lacsie daardoor als her ware een schot hagel dat niet alleen delen van her taalsysteem treft, maar eveneens functies die in hetzelfde verzorgingsgebied van het getroffen bloedvar liggen. Daar bovenop komt nog de complicatie dat geen cwee laesies herzelfde zijn.

- De Amerikaanse netroloog Knight heefr cen aanpak ontwikkeld dic dit probleem ten dele ondervangt. Bij een groot aannal patiëıten met een bepaatde cognixieve uirval wotdt het gebicd bcpaald waarin de laesies van al deze patiênten overlappen. Bij een groep patiënten met een ander vitvalspatroon wordt vervolgens nagegaan of in geen van deze gevallen de laesie zich bevindt in her gebied met honderd procent overlap van de eerste grocp pariënten. Indien aan dic voorwaarde is voldaan, kan met meer zekerheid worden angenomen dat her getroffen overlappende gebied te maken heeft met de functic die bij al deze patiënten gestoord is. Mer gebruikmaking van deze methode heeft Dronkers (1996) recent kutsnet vaststellen dat het voorste gedeelte van de instla in de liuker hersenhelft een belangrijke rol speclx bij de planning van 
de articularorische bewegingen. Alle patiënten mer een laesie in de precentrale gyrus van de linket insula verroonden een verbale apraxic. Het betreffende hersengebied is gelegen onder de frontaal- cn temporaalkwab, an het mediale uireinde van de groeve van Sylvius.

Een laatste complicatie bij laesiestudies wordt gevormd door de individuele variatie in de exacte relatie tussen taal en hersenen. Vermoedelijk bestaat binnen de grenzen van het perisylvische gebied in de linker hersenhelti de nodige variatie tussen individuen in het netwerk van gebieden dat veranxwoordelijk is voor een bepaald aspect van ons taalvermogen. Dit probleem van de individuele variatie is overigens niet uniek voor de laesiemerhode, maar geldt evenzeer voor scanning van hersenactiviceit waarbij over meerdere proefpersonen gemiddeld wordt. Er onrstaar de Jaatste jaren steeds meer belangstel ling voor de individuele variatie die het algemene bouwplan van de hersenen tosstaat bij dc anleg van de nemrale architectuur voor ral ch andere cognitieve functies.

Ondanks de genoemde beperkingen van de laesiemerhode, is de verwachting gerechrvaardigd dar deze methode, vooral in samenspel met andere hersenscanningstechnieken, waardevolle informatie zal leveren voor een verdere invulling van de neurale architectuur van her menselijk taalvermogen.

\subsection{DE ELEKTROFYSTOLOGISCHE METHODE (ERPS)}

Informaticoverdracht in her centrate zenuwstelsel vindt plaacs door middel van elektrische activiteit van de zenuwvezels en de zenuwcellen (figuur 2). Hans Berger (2873-1941) publiceerde in 1929 een methode om deze elektrische lrersenactiviteir bij mensen te registreten met behulp van op de schedel bevestigde ctektroden. Het resulterende EEG (elektro-encefalogram) heeft sindsdien een belangrijke rol gespeeld in de klinisclie diagnosciek bij patiënten met hersenaandoeningen.

Het klinische EEG geeft een globaal beeld van de elektrische activireit van de hersenen onder bepaalde algemane condities van het organisme, zoals slapen of waken. Het is echter aok mogelijk gebleken het $\mathrm{EBG}$ te registreren in afhankelijkhcid van specifieke sensorische, motorische en cognitieve processen. Indien men het EEG registreert terwijl door de proefpersoon of patiēnt naar een bepaalde srimulus geluisterd of gekeken wotdt en dit EEG vervolgens wordt gemiddeld oyer een aantal aanbiedingen van de stimulus, dan zien we een identificeerbaar patroon van negatieve en positieve pieken in het EEG-signal ontstaan (figuur 5). Deze pieken zijn de zogenaamde ERP-componenten, 
waarbij ERP staat vook event-telated potentials. Deze ERPs geven onder andere informatie over de aard van bepaalde cognitieve processen, zoals het voorbereiden van een beweging, het registreren van een onverwachte gebeurtenis, cnzovoort (Hagoort \& Brown, 1993).

EEG-activireic
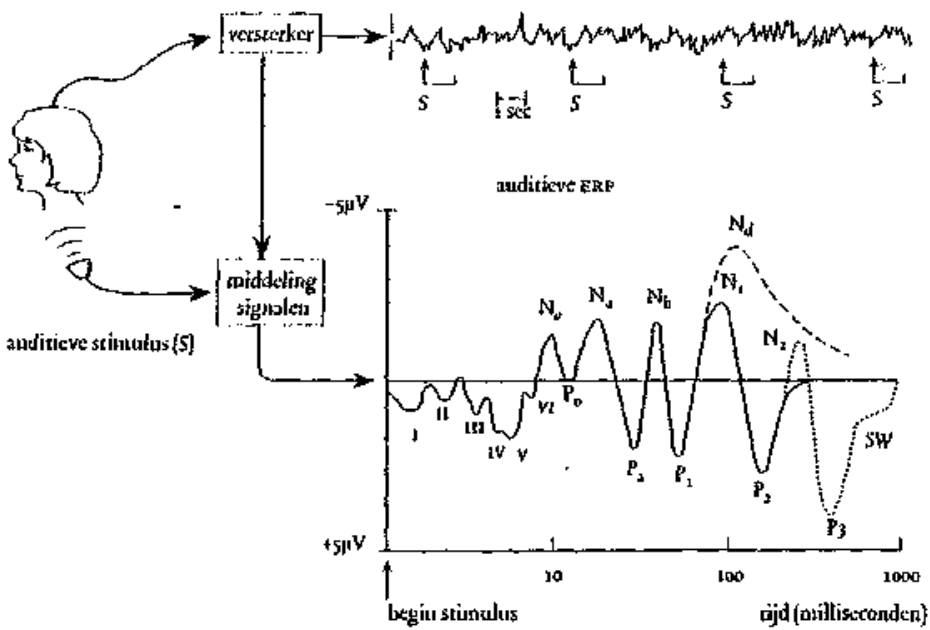

Figuur 5 | Geïlealiscerd golfpatroon van de reeks ERP-componenten die zichtbaar worden wanneer her EEG gemiddeld wordt over de herbaxlde aanbiedingen van ecn korte auditieve stimulus. Op de logaritmische tijdas zijn achtereenvolgens zichtbaar de vroege hersenstampotentialen (golven I-vI), de zogensamde middenlatenticcomponenten (No, Pa, Na, P1, Nb), de exogenct componenten (P1, N1, P2), en de endogene, cognititve erPcomponenten ( $\mathrm{Nd}, \mathrm{N}_{2}, \mathrm{P}_{3}(\mathrm{c})$. De componenten met een negaticyc polariteit zijn omhoog geplot, de componenten met een positieve polariteit hebbea ecn max beneden gerichte piek (Hagoott \&2 Brown, 1993).

ERPS worden doorgaans opgewekt door aan cen proefpersoon verschillende keren een bepaald type stimulus (bijv. een toon van cen bepaalde frequentie of een woord van een bepaalde klasse] aan re bieden. Tegelijkertijd wordt bij de proefpersoon het EEG geregistreerd. Meestal gebeurt dit over meerdere afleidingen, dar wil zeggen meerdere elektroden zijn in een bepaalde ruimtelijke configuratie op de hoofdhuid bevestigd. Nadat het EEG geregistreerd is voor 
een bepaald aantal exemplaten van het aangeboden stimulustype, volgt een middeling van de afzondẹrlijke stukjes $\mathrm{EEG}$ die door deze exemplaren zijn opgewekt. Figuur 5 laat het door een auditieve srimulus (S) opgewekte golfparoon zien. Gemarkeerd is her moment waarop de stimulus wordt aangeboden. De ERP is doorgaans te klein om in het EEG te worden opgepikt, waardoor middeling per computer over meerdere stimuluspresentaties vereist is om een adequate signaal-trisverhouding te bereiken. In het resulterende ERP-patroon zijn verschillende componenten te identificeren. Deze identificatie geschiedt op basis van een aantal kenmerken yan het signaal.

Het eerste kenmerk is de polariteit van een ERP-component. Wat bij ERP-registraties in feite wordt opgepikt is een potentiaalverandering in het elektrische veld tussen de elektroden op de hoofdhuid en een electrode (bijv. op de oorlel) die geen hersenactiviteit oppikt. De potentiaalverandering kan negatief of positief zijn, resulterend in een ERP-component met een negatieve of een posirieve polariteit. ERP-componenten met een negatieve polariteir worden veelal weergegeven door middel van een omhoog gaande piek, componenten met een positieye polatiteit doot middel van een omlaag gaande pick. De benocming van de componenten bevat meescal informatie over hun polariteit ( $N$ of $P$ ).

Een tweede kenmerk is het moment waarop de component optreedr. Het gaar hier om de pieklatertie ten opzichte van het moment waarop de stimulus gepresenteerd is. $Z 0$ is bijvoorbeeld de $P_{3} \infty$ een ERP-component mer een positieve polariteir waatvan de maximale amplitude optreedt on en nabij de 300 mitliseconden na de presentarie van een stimulus.

Fen derde kenmerk is de anplituderariatie van een bepalde component. Deze anplitudevariatie kan samenhangen met fysieke stimulusparameters (5) [bijv. de lutdheid van een toon], maar ook met bepaalde cognitieve variabelen (bijv. de semantische verwantschap tussen woorden).

Ten slotte is de topografisclie verdeling van een ERP-component over de schedel van belang. Omdat ERPS meestal over meerdere afleidingen geregistreerd worden, kan worden vasigesteld op welke afleiding de component zich het duidelijkst manifesteert. De $P_{300}$ bijvoorbeeld vertoont achter op de schedel (posterieur) een grorere amplitude dan voor op de schedel (frontaal).

\section{ERPsen netrrale arditectuntr}

Bij ecn specificatic van de neurale architectuur zijn minimal de volgende twee aspecten van belang: 
1 Welke hersengebieden zijn betrokken bij een bepaalde cognitieve functie en wat is hun precieze bijdragc?

2 Wanneer worden de betrokken hersengebieden actief in de cascade van operaties die onder de paraplu van een bepaalde cognirieve functie vallen?

Zeker bij her produceren van en hisreren uaar spraak is het onvoldoende te weten waar zich dat in het brein afspeelt. Een centraal kenmerk van de betrokken processen is de snelheid waarmee ze verlopen en de onderlinge temporele afstemming van deze processen die nodig is voor een effectief verloop. Een specificatie van de neurale architectuur van her menselijk taatvertnogen moet asn deze spatioremporele dynamiek recht doen. De vragen 'waar' en 'wanneer' dienen beide beantwoord te worden.

Het tijdsoplossend vermogen van ERPS is vele maten beter dan dat yan andere hersenscanningstechnieken. Elektrofysiologische registraties kunnen daarom met name bijdragen aan het achterbalen van de remporele parameters van de bij talfuncties berrokken processen (figuur 8).

De eRP-methode is vooralsnog minder geschikt om te bepalen welke hersenstructuren bij talfuncties betrokken zijn. Dit heeft te maken met het zogeheten inverse probleem. Om te bepalen waar de aan de schedel opgepikte elektrische hersenactiviteit wordt gegenereerd, kijkt men naar de topografische verdeling van deze activiteir over de schedel en probeet men via mathematische technieken op basis daarvan de plaats van de neurale bronnen te bepalen. Het probleem is dat deze bepaling geen unieke oplossing kent. Door dit inverse probleem is het dus niet mogelijk met zekerheid te zeggen waar de elektrofysiologische activiteit in het brein wordt opgewekt. Ondanks de ontwikkeling van nieuwe analyserechnieken, is vooralsnog niet te voorzien dat op korte termijn een precieze bepaling mogelijk is van de hersenstracturen die verantwoordelijk zijn voor alige ER P-conponenten.

\subsection{MaGNeto-ENCEFAlOgRAFIE (MEg)}

Inhtrent aan de intrinsieke relatie tussen clektrische velden en magneetvelden is dar de elektrische activiteit van de hersenen ook een magneetveld genereert. Dit magneerveld is uiterst zwak. Onder de juiste atscherming van andere magneetvelden en mer gebruikmsking van de eigenschappen van supergeleiding is her tegenwoordig mogelijk de magnetische activiteit van de hersenen te meten. Dit gebeurt met behulp van een magneto-encefalograaf waarvan het 
nieuwste prototype een registratie op meer dan driehonderd plaatsen over het hoofd mogelijk maakt.

Met betrekking tot her gebruik van MEG voor cognitieve studies gelden in veel opzichten dezelfde mogelijkheden en beperkingen als voor her EEG (ERPS). Aangezien tot op heden MEG-studies geen substantiele bijdrage geleverd hebben aan onze kennis over de neurale architectuur van taal, zullen we deze rechniek verder onbesproken laten (zie hoofdstuk A9.5 voor een bespreking van de $M E G-$ rechniek].

\subsection{MATEN GERELATEERD AAN METABOLE HERSENACTIVITEIT}

Lassen en Ingvar slaagden er in 1960 als eersten in functionele beelden van hersenactiviteit te maken met behulp van een techniek die een voorloper vormde van SPECT: single photon emission tomography. In patiënten die aan radiografisch onderzoek van de cerebrale arteriën moesten worden onderworpen, injecteerden zij kleine hoeveelheden Xenon-133, een radioactieve stof die elektromagnetische straling (fotonen) in de cerebrale atterièn uitzende. Deze straling kon buiten her hoofd worden gedetecteerd door middel van een scanner die bestond uit een reeks van kleine detectoren. Op deze wijze verkregen Lassen en Ingvar tweedimensionele karten van de stralingsintensiteit. Het bleek dat de verdeling van de radioactieve stof in het brein afhankelijk was van hersenactiviteit. Patiënten die hun vingers bewogen vertoonden een verhoogde stralingsintensiteit over de motorische schors. Bij patiènten die luisterden naar een auditieve stimulus werd een verhoogde intensiteit over ternporale gebieden geregistreerd.

(9) De technieken die tegenwoordig het meest gebruikt worden bij het visualiseren van hersenactiviteit (functional imaging) zijn PET (positron emissie romografie) en fMrI (functionele magnetische tesonantie imaging). Deze rechnieken berusten op hetzelfde principe als SPECr. Dit principe is het zichtbaar maken van de lokale toename van de doorbloeding die samenhangt mer de activatie van hersenweefsel. Hoewel we daarbij de neurale activiteit van een lokale groep zenuwcellen tiet direct kunnen warnemen, is het inditect mogelijk deze activatie te lokatiseren door de toename in de doorbloeding in de buurt van het gexcriveerde hersenweefsel te derecteren. De correlaten van neurale activiteit worden kortom via een vasculair filter gedetecteerd. 
Positronen entissic tontografie(PET)

Hoewel PET en SPECT op vergelijkbate principes berusten, is het belangrijke voordeel van PET gelegen in het toegenomen tuimtelijk oplossend vermogen. Daardoor is een preciezere lokalisatie van hersenacriviteit mogelijk. Deze verbetering hangt samen met de radioactieve substanties die bij PET gebruikt worden. Deze zenden posirronen uit in plaats van gammaforonen. Positronen zijn declrjes die in omvang en massa gelijk zijn aan elektronen, maar een tegenovergestelde lading hebben. Elektronen zijn in alle lichaamsatomen aanwezig. Positronen komen daarentegen alleen voot op plaatsen waar de radioactief gemaakte substantie zich ophoudt. Indien een positief geladen positron in aanraking kont met een negatief geladen elekrron wordt de rasssa van deze beide deeltjes volledig ongezet in twee gammatotonen die in tegenovergestelde richting worden uitgezonden. Deze worden door een PET-camera geregistreerd (figutur 6). Een fotonenpaas dat vanuit een punt in de hersenen met de snelheid van het licht in tegenovergestelde richtingen wegvliegt, treft gelijktijdig twee detectoren van de ring. Deze gebeuttenis worde door de met de detectoren verbonden coinncidentie-elektronica geregistreend. Doot detecrie van ook andere fotonenparen die vanuit hetzelfde hersengebied in andere richtingen vliegen, kan dit hersengebied uiteindelijk als oorsprong gereconsrrueerd worden.

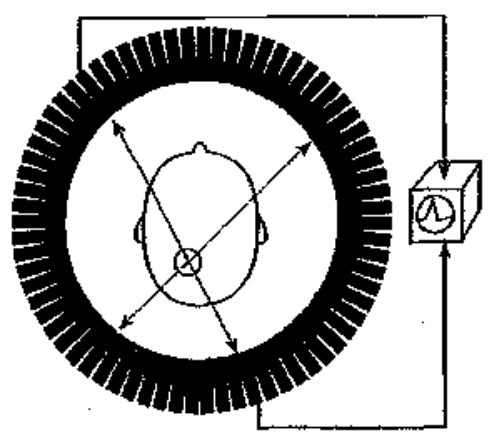

Figutat 6 | Principe van de pet-camera.

Het oplossend vermogen van PET is beperkt tot enkele millimeters. De belangrijkste teden van deze beperking is dat de positronen gemiddeld een afstand van ongeveer dtie millineter afleggen alvorens in botsing re komen met een elekrron. 
Om uit de geregistreerde fotonenpaten een beeld van hersenactiviteit te kunnen reconstrueren is een groor aantal fotonenpaardetecties vereist. Daarom heeft de PET-camera tienden van seconden nodig om voldoende daca te kunnen verzamelen. Aangezien cognitieve processen veelal in hondersten van milliseconden verlopen, betekent dit dat het temporeel oplossend vermogen (de temporele resolutie) onvoldoende is voor bet bestuderen van de temporele dynamiek (de 'wanneer' vraag) van deze processen. Een bijkomende handicap is dat in PET-onderzoek cen bepaalde experimentele condirie als geheel moer worden aangeboden gedurende een meerperiode van ongeveer rwee minuten. Dit in tegenstelling tot het gangbare cognitieve experiment waarin de items uit de verschillende experimentele condities gerandomiseerd worden.

Voor her meten van aan cognitieve processen gerelateetde hersenacriviteit wordt vooral radioactief gelabeld $\mathrm{O}-15$ gebruikt. Dit zuurstofatoom kan worden ingebouwd in water, $\mathrm{CO}_{2}$ of butanolmoleculen. O-15 heeft een halfwaatderijd van twee minuten. Dat wil zeggen dat de uitgezonden straling in deze periode halveert. Na vijftien minuten is de straling tot het normale niveau teruggekeerd en kan een volgende meetsessie van ongeveer twee minuten beginnen. Het totaal anntal metingen words beperkt door scringente bepalingen omtrent de stralingsbelasting waaraan proefpersonen mogen worden blootgesteld.

Functionele nagnetische resonantie imaging ( $(\mathrm{MRI})$

Magnetische resonantie imaging (MRI) is een techniek die gebruik maakt van het feit dar de kernen van bepalde atomen zich gedragen als kleine magneten met cen magnetische noord- en zuidpool. Een voorbeeld daarvan zijn de protonen die de kern vormen van de waterstofatomen in ons lichaam. Net als bij een elektrische generator kan een draaibeweging van deze atoomkernen in principe een elektrische wisselstroom in een spoel induceren. Om dit signaal ook feitelijk te kunnen oppikken moet een zeer groot aankal protonen tegelijkertijd precies dezelfde beweging ten opzichte van een metingsspoel maken. Om dit te bereiken wordt bij een MRI-meting het lichaam in het magneetveld van een krachrige magneet geplaarst, waardoor de protonen zoals kompasnaalden in een bepaalde richting wotden gedwongen. In plaats van hun gewone chsotische bewegingen tonen ze nu een draaibeweging met een frequentie die afhankelijk is van de sterkre van her magnetische veld. Deze natuurkundige eigenschap wordt gebtuikt om de protonen die zich op verschillende plaatsen in het brein bevigden een katakteristieke frequentie te geven. Dit wordt bereikt door de sterkte van het magnetische veld in de mai-scanner in de drie dimensies te laten variëren. 
Bij de feitelijke meting wordt vervolgens een kortdurende elektromagnetische golf(radiopuls) van een bepaalde frequentie door her hoofd gestuurd, dat zich bevinde in her magneerveld van de scanner. De energie van deze tadiopuls wordt door protonen met een zelfde frequentie genbsotbeetd (vandaar resonanric). Dit vetandert de draaibeweging van de protonen zodanig dat ze gedurende en korte periode synchroon in de richting van een metingsspoel draaien, waarin ze ecn wisselscroom (her signaal) opwekken. Ondat dit signaal een kakakteristieke frequeatie heeft, is het mogelijk te bepalen op welke plaats in de lichanm (i.c. her brein) de protonen die her signaal hebben opgewekt, zich bevinden.

$\mathrm{Na}$ afloop van de kortdurende puls verliezen de protonen de energie van de elektromagnerische golf en keren ze terug in de tichting van het uiterijke nagnectveld. Daarbij verdwijnt her signaal (figuur 7 ).
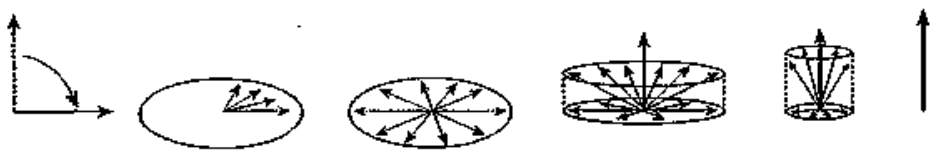

Figuar 7 | De twee mechanismen van signaalverlies bij MIR. Van links naar rechts: een radiopuls leeft de draaibeweging van de protonen $90^{\circ}$ in rickting van de metingsspocl veranderd en de protonen drapien synchroon. Het maximale signaal wordt geregistreerd. Na een korte periode beginnen de protonen al niet meer synchroon tedranien. Ten slotte verlaten ze ook her $90^{\circ}$-vlak en gaan terug naar hun uitgangspositie. Er wordt geen signaal meer geregistreerd.

De snelheid waarmee de protonen terugkeren is afhankelijk van het biologische weefsel. Her signaal van zenuwweefsel verdwijnt bijvoorbeeld sneller dan het signal van water. Als op het juiste moment gemeten wordt en de verschillen in signaalsterkte ongezet worden in helderheidsverschillen, ontstaat een anatomisch beeld van de hersenen.

Het gebraik van MRI voor het registreren van hersenactiviteit (fMRl) berust op een tweede bron van signaalverschillen. Het signaal verdwijnt namelijk ook indien de draaibeweging van de protonen niet meer synchroon is. In dar geval wekr het ene proton in de spoel een positief elektrisch signaal op, terwijl een ander proton een negatief signaal opwekt. Deze signalen nearraliseten elkaar. De draaibeweging van de ptotonen wordt onder andere asynchroon dootdat het weefsel in hun omgeving een onregelmatige magnetische invloed uitoe- 
fent, waardoor de beweging van sommige protonen versneld wordt en die van andere vertraagd, Een dergelijke magnetische invtoed wordt in het lichaam uitgeoefend door het bloed dankzij het ijzergehalte in de rode bloedkleurstof (hemoglobine). Bovendien is al langer bekend dar de hoeveelheid zuurstof die door het hemoglobine gebonden en gerransporteerd wordt de magnetische eigenschappen van het bloed beïnvloedt. De toename in de zuurstofconsumptic door acrieve hersengebieden leidt om nog onbekende redenen tot een meer dan evenredige toename in de zuurstoftoevoer (hyperperfusie). Een groot deel van deze extra toegevoerde zuurstof wordt daarom weer via de venen afgevoerd. Deze fluctuaries in de zuurstotbalans (en dus in de magnerische eigenschappen van het bloed) kunnen in het $M R$-signaal worden opgepikt.

In 1990 toonden Ogawa en zijn collega's aan dat veranderingen in de oxygenarie van bloed de intensiteit van het MR-signaal inderdaad beinvloeden. Her resulterende contrast in het signaal wordt BOLD-contrast genoemd (blood oxygenarion level dependent). Twee jaar tater publiceerden Kwong en zijn collega's (1992) de eerste fimRl-meringen in de visuele schors en de mororcortex, mer gebruiknaking van de BorD-techniek.

In vergelijking mer PET scanning heeft fMrı ber voordeel dat proefpersonen niet aan radioacrieve straling worden blootgesteld. Bovendien is de temporele resolutie van fMRI aanzienlijk beter dan die van PET. Aangezien het signaal ook bij fAMI afhangt van de toename in bloed toevoer, is aok het tijdsoplossend vermogen van fMR! vict ideaal. De fysiologische ondergrens van de temporele resolurie wordt bepaald door de traagheid van de hemodynamische respons die in de orde van enkele seconden is.

Het ruimtelijk oplossend vermogen van fmat hangt ervan af hoe ver in het afyoerend vaststelsel BoLD-contrasten nog worden gedetecteerd. Op dit moment kan worden gezegd dat in de praktijk het ruimtelijk oplossend vermogen van PET en FMRI van dezelfde ordegrootte zijn. Aangezien in kegenstelling tot PET bij FMR tegelijkertijd informatie over de anatomische structuren wordt binnengehaald, geldt dat bij het analyseren van de gegevens van afzonderlijke proefpersonen de lokalisatie berrouwbaarder is. Daartegenover staat het nadeel dat FMRI op dit moment gevoeliger is dan PET voor bewegingsartefacten, waaronder fysiologische bewegingen gerelateerd aan hartslag en ademhaling.

Figuur 8 geeft weer hae de verschillende onderzoeksmethoden zich in hun"temporele en ruimtelijke resolutie tot elkaar verhouden. 


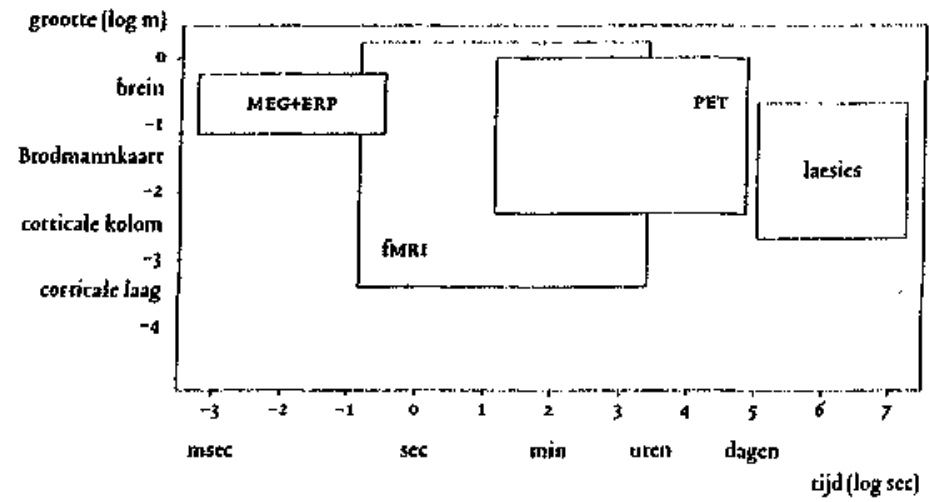

Figuur 8 | Samenvattend overzicht van de spatiotemporele resolutie die de verschillende methoden van hersenonderzoek kenmerken. De Y-as geeft op een logaritmische schaal de omvang weer van de hetsenstracturen die voor het signanl verantwoordelijk zijn. De $X$-as geeft het tijdsoplossend vermogen van de verschillende methoden weer. Deze as representeert de tijd in de logatitmen van seconden.

Uit de bespreking van thans beschikbare onderzocksmethoden om de neuralc architectuur van het menselijk taalvermogen te bestuderen, blijkt dat geen van deze methoden alleenzaligmakend is. Vooruitgang in onze kennis zal vooral ontstaan door de resultaten die met elk van deze methoden zijn verkregen te combineren. Nog beter is het bij dezelfde personen mer hetzelfde materizal verschillende hersenscanningscechnieken (bijv. ERP en EMRt) regelijkertijd toe te passen. Aan het combineren van technieken (coregistratie) wordt op dit moment hard gewerke. Wat de precieze winst daarvan is, zal echter pas op termijn duidelijk worden.

\section{De neurale arclitectuur van caalfuncties}

In het vervolg van dit hoofdstuk zullen wij een schets geven yan de neuralc axchitecturur van het menselijk taalvermogen op basis van de beschikbare literatuur. Daarbij moeten we vooraf een tweetal kanttekeningen maken. Hoewel taal de laatste jaren een populair onderwerp is in hetsenscanningsstudies, zijn de resultaten van verschillende studies verre van eensluidend (Poeppel, 1996). Kinderziekten van deze nieuwe en complexe methoden, waronder het vinden van de juiste experimentele aanpak en de juiste wijze van dataverwerking, spe- 
len daarbij ongetwijfeld een voorname rol. Daarnaast zijn er voor sommige aspecten van taalverwerking opvallende verschillen tussen de uitkomsten van laesiestudies en PET-studies (Stromswold c.a., 1996 vs. Caplan e.a., 1996). Het voert te ver in het kader van dit hoofdstuk een uitputtende opsomming te geven van al deze verschillen en hun mogelijke oorzaken. Wat hierna volgt is en samenvattend beeld op basis van de nu beschikbare studies. Door de genoem de factoren kan een dergelijke schets niet anders zijn dan een momentopname. De snelle ontwikkelingen in de cognitieve neurowerensclap wetrigen de verwachting dat bijstelling en anurtling van deze momentopname aanstaande zijn. De houdbaakideid van dit hoofdstuk is dus beperkt.

De tweede kanttekening is dat de weging van de beschikbare evidentie in het liche van de geschetste stand van zaken niet ontkomt an een bepaalde mate van persoonlijke inkleuring. Wat in het vervolg van dit hoofdstuk zal worden opgediend is een specificatie van de neurale architecturur van taal zoals die op dit moment naar ons beste weten te geven is op basis van de beschikbare gegevens. Daarbij zullen we een onderscheid maken tussen enerzijds de verwerking van afzonderlijke woorden tijdens lezen, luisteren en spreken, en anderzijds het ptoduceten en begtijpen van woorden in de context van hun natuurlijke omgeving: zinnen. Bij de bespreking van zinswerwerking besteden we met name aandacht aan de neuale architectuur van syntax, het cement tussen de losse bouwstenen van een zin.

\subsection{DE NEURALE ARCHITECTUUR VAN WOORDVERVERKING}

In tegenstelling tot wat vecl mensen denken, liggen woorden nier als kant-enklare pakketjes in ons brein opgeslagen. Afhankelijk van wat wij met woorden doen, wordt een heel netwerk van hersengebieden geactiveerd en neuraal georkestreerd. Bij lezen, luisteren en spreken van woorden zijn ten dele dezelfde en ten dele verschillende hersengebieden betrokken. In alle gevallen is het echter nodig onderscheid te maken tussen hersengebieden die met de fonologische of orthografische structuur van woorden te maken hebben, gebieden die samenhangen met de activatie van woordbetekenissen en gebieden die bij het aanstuten van articulatic betrokken zijn.

\section{Het lezen van woorden}

$\mathrm{Bij}$ het lezen van woorden worde de visucle informatie die op ons netwlies valt in eerste instantie doorgeschakeld naar de primaite visuele schors die zich achter in de occipitaalkwab bevindt, in gebied 77 van de Brodmannkast. Deze informatie worde vervolgens verder verwerkt in de ventrale stroom van visuele 
gebieden die zich vanaf de occipitaalkwab titstrekken tot gebieden in de onderste winding van de temporaalkwab. Met name de gyrus fusiformis speett daarbij een belangrijke rol in de verwerking van letterrecksen die an de orthografische regelmatigheden van de taal voldoen. Dic lijkt te gelden voor zowel de gyrus fusiformis in de linker hersenhelft als die in de rechter heisenhelft. Hoe groter het aantal woorden is dat veiwerkt moet wotden, hoe groter de activatie in dit gebied. Bovendien lijkt de activatie groter voor lecterreeksen die geen bestaande woorden vomen (pseudowoorden) (Hagoort e.a., 1997; Pricc c.a., 1996a). De genoemde gebicden in de ventrale stroom van visuele informatieverwerking zijn overigens niet alleen voor her herkennen van woordpatronen van belang, maar ook voor het herkennen van gezichten, objecten, enzovoort.

Uit ERP-onderzoek is bekend dat het 60 milliseconden duurt alvorens de visuele informatie op de retina de primaire vistuele schors bereikt hecft. Vervolgens duurr het nog ongeveer 90 milliseconden om letterreeksen als bestaande woorden te herkennen. Binnen 280 milliseconden kumen verschillende woordklassen, zoals functiewoorden en inhoudswoorden, van elkaar worden onderscleeiden. In minder dan 400 milliseconden is ten slotte de betekenis van een woord in de interpretatic van de voorafgaande zinscontext geïntegreerd.

Ecn intcressante bevinding in hersenscanningsstudies tijdens bet stillezen van woorden is dac, ook al worden die woorden nict uitgesproken, et toch gebieden worden geactiveerd die bij het omzetten van een orthografische in een fonologische code betrokken zijn, alsmede gebieden die vetantwootdelijk zijn voor het voorbereiden van de articulatiebewegingen (Hagoote e.a., 1997; Price c.a., 1996b). Kennelijk ontkomen zelfs geoefende lezers er niet aan deze bij spraak betrokken gebieden automatisch te activeren, ook al lijken ze voor het lezen van woorden niet strikt noodzakelijk te zijn.

In het klassicke Wernicke-Geschwind-model werd de gyrus angularis gezien als het doorschakelstation van orthografische naar fonologische woordinformatie. Voor het omzetten van een visuele woordcode nar cen auditieve woordcode zou de gyrus angularis onontbeerlijk zjjn. Recente PET-studies leveren geen eenduidig beeld op met betrekking rot de rol van de gyrus angularis. Sommige studies vinden ondersteunende cvidentie voor het klassieke model, andere studies daarentegen hebben geen bewijs kumnen vinden voor een tussenkomst van deze gyrts bij het verklanken van geschreven woorden. Ook de rol van de gyrus supramarginalis is in recent hersenscanningsonderzoek nier opgehelderd. 
Uiteraard worden tijjdens het lezen van woorden ook de gebieden geactiveerd waarin de betekenis van die woorden ligt opgeslagen. Hietbij zijn met name de linker temporaalschors en mogetijk ook de onderste gyrus in de frontaalschors van belang. In de tempotaalschors is van oudsher het gebied van Wernicke geassocicerd met woordbetekenis. Niet alleen de bovenste gyrus van de tempotaalschors, maar ook de middelste en onderste temporaalgyrus lijken betrokken te zijn bij bet verwerken van woordbetekenis (Pugh e.a., 1996; Vandenberghe e.a., 1996).

Hoewel op grond van laesiestudies de betrokkenheid van de temporaal$\mathrm{kwab}$ bij het verwerken van woordbetekenis bekend was, kwam de berrokkenheid van de linker frontaalkwab als een vertassing. Deze betrokkenheid was niet bekend uit dergelijke studies, traat werd geconcludecrd uit een van de meest robuuste en gerepliceerde resultaten van PET-studies. Het gaat daarbij om activaties verkregen in de zogenaamde werkwoordenoproeptaak (verb generate task]. In deze taak krijgen proefpersonen zelfstandige naamwootden te lezen (bijv. 'kip'). De taak van de proefpersoon is een daarbij horend werkwoord te produceren (bijv. 'kakelen'). De achterliggende gedachte is dat het produceren van zo'n werkwoord een semantische analyse van het zelfstandig naamwoord vereist. In de vele PET-studies waarin yan deze taak gebruik gemaakt is, werd scelselmatig activatictoename gezien in de linker frontaalschors. Deze activatic werd toegeschreven aan de vereiste semantische analysc. Om die reden heeft de gedachte post gevat dat ook de linker frontaalschors deel uitmaakt van het nerwerk van hersengebieden dat bij woordbetekenis betrokken is. Deze interpretatie is echter voot discussie vatbaar. Een andere mogelijkheid is dat de linker frontalschors bij de planning en uitvoering van gedrag betrokken is. Het genereren van een werkwoord bij een zelfstandig naanzwoord is daarvan een voorbeeld, maax de alard van de acrivatie is in dar geval veel algemener en niet direct samenhangend met de semantische analyse die voor het oproepen van her juiste werkwoord vereist is.

De verschillende interptetatiemogelijkheden duiden op een belangrijke kwestie in hersenscanningsonderzoek. Deze heeft betrekking op de keuze van de controleconditie. De achterliggende gedachte bij veel hersenscanningsonderzoek is dat hersenactiviteit in een conditie waarin de bestudeetde cognitieve component geen rol speelt, moet worden afgetrokken van een conditie waarin deze wel relevant is (dc subtractiemethode). Het gebied waarin de lokale bloedtoevoer toeneemt in de vergelijking tussen deze twee condities (scans) zou dan met de betreffende cognitieve component samenhangen. Vaak is her echter nick zo eenvoudig vast te stellen of de twee vergeleken condiries alleen 
verschillen in de cognitieve component die bestudeerd wordt (bijv. semantische analyse), of dat er ook nog andere cognitieve verschillen zijn tussen de condities (bijv. het actief genereren van eetn ancwoord in de ene conditie versus her passief verwerken van een stimulus, zoals een woord, in de controleconditie). In dat laatste geval kan de toegenomen hersenactiviteit aan verschillende cognitieve componenten worden toegeschreven. Dit lijks onder andere te getden voor de getapporteerde hersenactiviteit in de linker frontaalschors. Vooralsnog is de rol van de linker frontaalschors bij de analyse van woordbetekenis dus onduidelijk. De laatste jaren zijn altetnatieve analysetechnieken in opkomst die de bezwaren van de subtractiemethode op zijn minst gedeeltelijk. ondervangen (Friston, 1997).

\section{Het fuisteren utar woorden}

Voor het luisteren naar gesproken woorden is de temporaalschors van eminent belang. Allereerst bevindt de primaire auditieve schors zich in Heschl's gyrus (Brodmanngebied 41 ) in het bovenste gedeelie van de temporaalkwab. Aangrenzend vinden we de secundaire auditieve gebieden (Brodmanngebieden 42 en 22). Dit zijn de eerste corticale schakelstations voor de verwerking van geluid, inclusief spraak. Voor het verwerken van de specifiek an talige klankreeksen gekoppelde fonologische informatie zijn met name delen van de bovenste en middelste gyrus van de temporaalkwab van belang. Deze twee temporale gyri lijken voor wat betreft taalverwerking een multifunctionele rol te spelen. Zoals we eerder hebben gezien zijn deze gebieden ook van belang voor de verwerking van de betekenis van woorden. Zowei voor de taalgebieden in de frontalkwab (0.a. gebied van Broca) als voor deze gebieden in de temporaalkwab geldt dat we daabinnen vermoedelijk te maken hebben met een netwerk van kleinere gebieden die elk hun eigen bijdrage aan de uitvoering van een bepaalde raalfunctic leveren (Posner \& Raichle, 1994). Tegelijkertijd illustreert het dat we in het brein niet te maken hebben met taalcenter die geheel en al gespecialiseetd zijn voor slechts éen bepalde functie. Het organisatieprincipe is veeleer dat van 'a distributed nerwork in which nodal foci of relative specialization work in concert' (Mesulatn, 1990).

\section{Het spreken van woorden}

Bij her spreken van woorden is van belang dat de fonologische code van het woord word $z$ opgehaald en wordt omgezer in motorische programma's die via de motorische schors in beide hersenhelften de articulatieorganen activeren. Bij de feitelijke articularie spelen zowel de mototcortex als het centrale gedeelte van het cetebellum (de vermis) een belangrijke rol. 
Een reeks van PET-studies heeft uitgewezen dat het gebied yan Broca bij fonologische aspecten van woordverwerking betrokken is. Hoewel de precicze karakterisering van de bijdrage van dit gebied nog niet volledig duidelijk is, lijkt het erop dat met betrekking tot spteken het gebied van Broca betrokken is bij de assemblage van de fonologische code die nodig is on de articulatorische planning aan te sturen. Met betrekking tot de articulatorische bewegingen die de motorcortex instrueren om de feirelijke articulatie uit te voeren is er enige evidentie dat de laterale premotorcortex in de linker hersenhelft en de supplementaire mototische schors (SMA) een wezenlijke bijdrage leveren. Tevens speelt het voorste gedeelte van de insula in de linker hersenhelft een rol in de articulatorische vootbereiding.

Uit recent ERP-onderzoek is inmiddels cen vrij nauwkeurig beeld verkregen over het temporele verloop van de processen die aan de eigenlijke articulatic voorafgaan. Als de betekenis en de syntactische woordinformatie (bijv. of her woord onzijdig ('het konijn') of mannelijk/vrouwelijk is ("de stoel')] uit het geheugen is opgehaald, duurt her ongeveer veertig milliseconden on het fonologische beginsegment van het woord uit her geheugen op te halen. Vervolgens komen de resterende segmenten beschikbaar. Als de beginklank van een wootd geactiveerd is, duurt het voor een woord van een tot twee lettergrepen nog ongeveer tachtig milliseconden om de resterende fonologische segmenten op te halen (Hagoort \& Van Turennout, 1997; Van Turennout e.a., 1997). Dit temporele verloop in het ophalen van wootdinformatie illustreert het eerdet besproken punt dat wootden niet als kant-en-klare pakketjes in ons brein liggen opgeslagen, maar elke keer opnietw uit de elementaire bouwstenen moeten woeden geconstrueerd. Teneinde dit te realiseren is dan ook elke keer opnietiw een heel netwerk van hersengebieden betrokken bij zoiets ogen* schijnlijk simpels als her lezen of spreken van een enkel woord. Figuur 9 geeft een samenvattend beeld van de hersengebieden die bij de verschillende aspecten van woordvcrwerking betrokken zijn.

\subsection{DE NEURALE ARCHITECTUUR VAN ZINSVERWERKING}

In vetgelijking met de hoeveelheid studies naar de neurale architectuur van woordverwerking, is het ancal hersenscanningsstudies naat zinsverwerking zeer beperkt. Dit hangt vermoedelijk samen met de moeilijkheid experimen-

i ten re ontwerpen warin de verschillende postlexicale processen kunnen worden geïsolcerd. Bovendien stant het taalpsychologisch onderzoek naar het produceren van hele zinnen nog in de kinderschoenen. Wel is het een en ander 


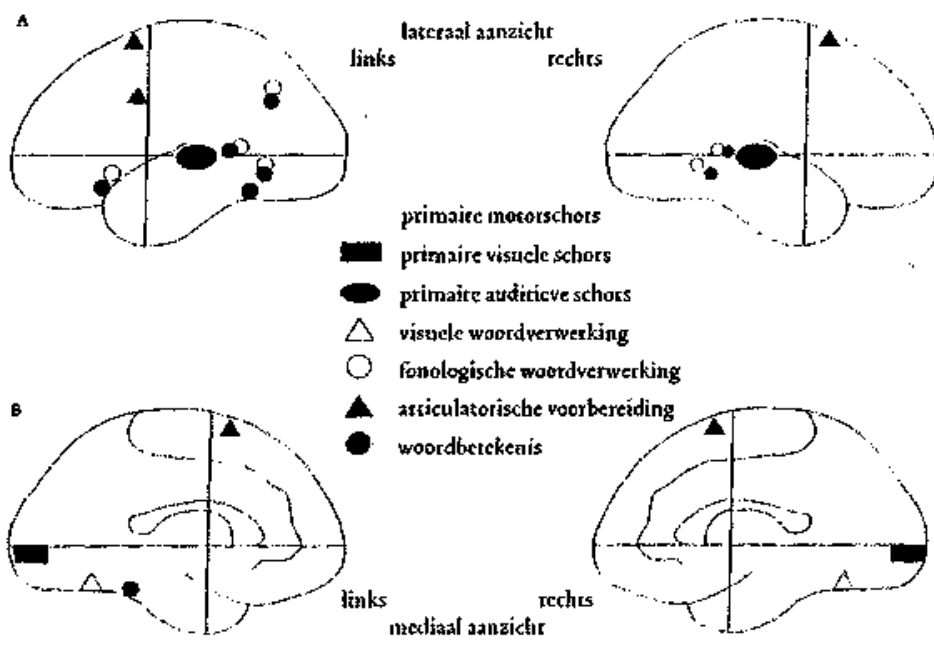

Figutrg | Een samenvatting van de gebieden dic bij woordverwerking betrokken zijn. (A) Zijaanzichten van de linker en rechter herscnhelft; (B) mediale aznzichten. De hotizontale referentielijin is de zogenoende AC-pc Iijn, gedefinieetd door twee goed identificeerbare structuten, de anterieurc en de postexieure commissuur. De verticale lijn vormt uer hoogte van de anterieure commissuur een rechte hoek met de AC-PC lijn. De ingetekende lijnen worden gebruikt on de resultaten van hersenscanningsstudies op een anatomisch gestandatardiscerde wijze te rapporteren. Primaike hersengebieden voor visuele/auditieve waarnening en motoriek zijjn grijs gekleurd. De lokalisatic van de verschillende aspocten van woordverwerking is schematisch aangeduid. De insula en het cerebeilum zijn in deze figunr nist zichtbaar.

bekend over postlexicale processen die bij het begrijpen een tol spelen. Met name richt het onderzoek zich daarbij op syntactische processen. Deze processen zorgen ervoor dat het structurele verband tussen de woorden in een zin wordt aangelegd. Door te achterhalen wat het onderwerp van een zin is, wat het lijdend voorwerp is, enzovoort, kan worden bepaald wie de in het werkwoord uitgedrukte handeling verricht (agens) en wie deze ondergaat (patiens). Het toekennen van deze thematische rollen vooronderstelt veelal duidelijkheid omtrent de grammaticale structutur van een zin. Om zinnen tc begrijpen is het dus nodig het syntactische verband aan te brengen. Bij bepaalde vormen van afasie Iukt dat niet langer. Bij patiënten met een dergelijke stoornis kan worden vastgesteld dat het taalbegrip ten dele gestoord is. 
Uit ERP-onderzock is gebleken dat componenten die met de betekenisintegratic van woorden in een zinscontext samenhangen, verschillen van componenten die op de verwerking van syntactische informatie reageren (Hagoort e.a., 1993; Osterhout \& Holcomb, 1992\}. Hocwel daaruit nict kan worden afgekid welke gebieden bij deze twee typen van postlexicale processen betrokken zijo, duidt hec kwalitatieve verschil tussen ERP-effecren van semantische en syntactische ard wel op de betrokkenheid van verschillende hersengebicden bij deze beide processen. Bovendien kan daaruit worden gecondudeetd dat betekenisintegratie binnen vierhonderd milliseconden voltooid is, terwijl het integreten van een woord in de syntactische structuur niet langer dan vijfhonderd milliseconden in besiag neemt.

Laesiestudies hebben azngetoond dat $\mathrm{d} c$ perisylvische gebieden in de linker hersenhelft cruciaal zijn voor syntactische processen. Echter op basis van deze studies is onduidelijk welke gebieden binnen dit omvangrijke geheel doorslaggevend zijn. De klassieke visie dat vooral het gebied van Broca hierbij een centrale rol speelt, is uireindelijk in laesíestudies niet bevestigd.

Om meer duidelijkheid te krijgen over de bij syntaxis bettokken gebieden is de laatste jaren een klein aantal hersenscanningsstudies verricht, met gedecltelijk dezelfde, gedeelrelijk verschillende uitkomsten. We zulien aan deze studies in her onderstaande in enig detail aandacht besteden, teneinde te laten zien warop bij complex hersenscanningsonderzoek gelet moet wotden.

Op dit moment zij̄n een vijfral PET-studies en tén fMRl-stưdie naar de neurale architectuur van syntaxis gepubliceerd (Indefrey e.a., 1996; Just e.a., 1996; Mazoyer e.a, 1993; Nichelli ea., 1995; Stowe e.a., 1994; Stromswold c.a., 1996). De moeilijkheid om syntactische processen te scheiden van fonologische en semantische zinsverwerkingsprocessen laat zich raden aan de diversiteit van experimentele ontwerpen die in deze studies gebruikt zijn. Tot de parameters die tussen studies varieexden behoren de aanbiedingsmodus (auditief vs. visueel), de manier van presenteren (hele zinnen vs. woord-voor-woord-presentatiej, het wootdmaterial in de zinnen (woorden ws. pseudowoorden), het type taak (begrips- vs. productietaken) en het type zinsstructuren. Het is duidelijk dat al deze parameters van invloed zijn op de interpretatie van de geobservectde hersenactiviteit.

De studie van Mazoyer e.a. (1993) bestond uit vijf condities waarin ralige stimuli auditief werden gepresenteerd. De taak van de proefpersonen was aandachtig te luisteren. In drie van de vijf condities (zinnen bestande uit pseudowoorden, semantisch abnormale zinnen en betekenisvolle zinnen die een verhaaltje 
vormen) was sptake van syntacrische processen. De hersenactiviteir in alle condities werd vergeleken met die in cen zogeheten rustconditic, watin geen ralig materiaal werd aangeboden. In beide hersenhelften werd in de anterietre tip van de temporaalkwab activatie gevonden die specifiek gerelateerd kon worden aan de verwerking van syntactische informatie.

Stowe en haar collega's (1994) presenteerden betekeniswolle zinncn vistseel en woord-voot-wootd. Drie typen zinnen werden gebruikt:

1 lange, syntactisch complexe zinnen;

2 korte, maar syntactisch ambigue zinnen;

3 korte, niet-ambigue zinnen.

De proefpersonen kregen de instructie de zinnen zorgvuldig te lezen orn et na afloop vragen over te kunnen beantwoorden. De tCB F (regional cerebral blood flow) in deze drie zinscondities werd vergeleken mer een rustconditie warrin ptoefpersonen natar een leeg scherm keken. Voor de syntactisch complexe en voor de ambigue zinnen rapporteerden de auteurs activatie in het gebied van Broca, op de grens van de Btodmanngebieden 44 en 45 . Activatie in dit gebied werd eveneens gevonden bij een directe vetgelijking van ambigue en nietambigue zinnen.

In alle condities van de studie van Nichelli e.a. (1995) kregen proefpersonen hetzelfde betekenisvolle verhaaltje te lezen, dat visueel en woord-voor-woord -werd gepresenteerd. In de syntactische conditie werd an de procfpersonen gevraagd de spartzaam optredende granmaticale fouten op te sporen. In de controleconditie moesten zij afwijkingen in het lettertype ontdekken. Een directe vergelijking van deze twee condities resulceende in activatie voor de syntacrische taak in de onderste frontaalgyrus van de rechter hersenhelft, in de gyrus cingularis en in de linker precentrale gyrus.

In de stadie van Stronswold e.a. (1996) werden zinnen vergeleken dic qua inhoud vergelijkbatar waten, mat in syntactische complexiteit verschilden ('The child spilled the juice that stained the rug.' vs. 'The juice that the child spilled stained the rug.']. De zinnen werden visueel in han geheel gepresenteerd. In beide zinstypecondities bevatte de helft van de zimnen ech semantische anomalie. De taak van de proefpersonen was de zinten op hun arceptabiliteit te beoordelen. Een directe vergelijking tussen de twee zinstypen liet voor de syntactisch meer complexe zinnen een activatietoename zien in het gebied van Broca (de pars opercularis in de onderste gyrus van de frontalkwab). 
In een fMRi-studie onderzochten Just en zijn collega's her effect van syntactische complexiteit op de activaties in het gebied van Broca en het gebied van Wernicke, alsmede van de homologe gebieden in de rechter hersenhelft. $\mathrm{Na}$ elke zin volgde een bewering die al dan niet overeenstemde mer de zinsinhoud. De proefpersonen moesten deze bewering als war of onwaar karakteriseren. De gepresenteerde zinnen verschilden in complexiteit. Behalve simpele actieve zinnen ('The reporter attacked the senator and admitted the error'), werden zinnen met een betrekkelijke bijzin gepresenteetd, waarin her onderwerp van de hoofd-en bijzin identiek waren ('The reporter chat attacked the senator admitted the error') of van elkaar verschilden ('The repotter that the senator attacked admitted the etrot'). Het blijkt dat proefpersonen de laatste soort bijzinnen moeilijker vinden dan de eerste soort. Voor dit yerschil worden door alternatieve taalpsychologische theorieën verschillende redenen aangevoerd, waarop we hier niet zullen ingaan. Zowel in het gebied van Broca als

* dat van Wernicke werd activatie gevonden voor alle zinstypen. In mindere mate wetd activatie gezien in de homologe gebieden in de rechter hersenhelft. Alle vier deze gebieden lieten een activatieroename zien bij oplopende syntactische complexiteit.

Indefrey en zijn collega's (1996) lieten proefpersonen hele zinnen lezen die bestonden uit pseudowoorden en echte functiewoorden (in het Duits: '(der Fauper) (der) (die Lüspeln) (febbr) (tecken) (das Baktor)'). De zinnen konden een syntactische fout bevatten (i.c. tecken). In één conditie moesteń de proefpersonen deze fout ontdekken en de zinnen in hun correcte vorm uitspreken ('Der Fauper, der die Lüspeln febbt, teckt das Baktor'). In een volgende conditie beoordeelden zij alleen de grammaticale contectheid en lazen de zinnen op zoals deze op het scherm stonden. Een derde conditie bestond uit het geven van fonologische acceptabiliteitsootdelen voor syntacrisch ongestructureerde recksell van pseudowoorden en functiewoorden ('Vormen deze pseudowoorden qua klankpatroon mogelijke woorden in het Duits?'). Al deze condiries werden vergeleken met een controleconditie waarin ongestructurecrde reeksen pseudo- en functiewoorden hardop gelezen moesten worden. Beide syntactische condities lieten activarie zien in het dorsale gedeelte van het gebied van Broca. Beide acceptabiliteitstaken (syntactisch en fonologisch) activcerden onder andere de anterieure gebieden in de onderste frontaalgyrus en het aan her gebied van Broca homologe gebied in de rechter hersenhelft. Het gebied van Wernicke werd geactiveerd in de conditie waarin de proefpersonen de syntactische acceptabiliteit moesten beoordelen. 


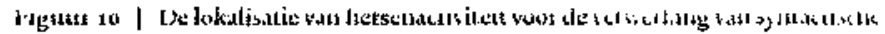
informatie, zoals gerapporterd in verschillende studies.

Figuur 10 geeft een overzicht van de geactiveerde gebieden in de zes besproken studies. Het algehele patroon van resultaten lijkt het belang van de klassicke taalgebieden (her gebied van Btoca en het gebied van Wetnicke) voor syntactische taalbegripsprocessen te bevestigen. In een aantal gevallen werd echter uitsluitend nazr deze gebieden gekeken (met name in de studie van Just e.a.) of werd het gebied van Broca temidden van andere geactiveerde gebieden als het syntaxis-relevante gebied aangeduid op basis van de klassieke literatuur (Stowe e.a., 1994). Een serietzzer probleem is dat in de meeste van deze studies nier aitgesloten kan worden dat er behalve syntactische ook semantische verschillen tussen de condities waten. Op basis van de ERP-Iiteratuur weten we dat deze processen zich binnen hetzelfde tijdsbestek voltrekken.

Slechts in twee studies (Mazoyer e.a., 1993, Indefrey e.a., 1996) zijn door het gebtuik van pseudowoorden de semantische verschillen tussen de condiries goeddecls getlimineerd. De resultaten van deze studies laten echter, nict-overlappende activaties zien. Het is mogelijk dat de activatie in de antericure temporaalkwab in de studie van Mazoyer e,a. te maken heeft met het aanbieden van gesptoken zinnen. In alle andere studies wetden de zinnen visueel gepresenteerd. De mogelijkheid van modaliteitsspecifieke gebieden voor de verwerking van syntactische informatie kan niet geheel worden uitgesloten.

Ten slotte werd in de meeste studies aan de proefpersonen gevrangd nier alleen de zinnen te lezen maar ook eventuele grammaticale of andere onvolkomenheden te detecteren. Mogelijk hangen sommige van de gerapporteerde activaties nict zozeer samen met het verwerken van specifiek syntactische 


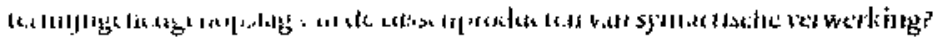

Is Is de syntactische betrokkenheid van het gebied van Broca vergelijkbaar of verschillend bij taalbegrip en taalproductie? Is de betrokkenheid heczelfde of verschillend voor auditicve en visuele inpur? Tevens roepen de laesiestudies de vraag op hoe noodzakelijk de bijdrage van het gebied van Broca is.

De tamelijk uirvoerige bespreking van het onderzock naar de neurale atchitectuur van syntaxis diende ter illustratie van de vele paradoxen en complexiteiten waarmee we daarin geconfronteerd worden. In vergelijking met de cognitieve modcilen van taajverwerking en ondanks een neuropsychologische traditic van ruim een eeuw, stat het onderzock naar de relatie tussen tal en hersenen nog mas in de kinderschoenen.

\subsection{DE ROL VAN DE RECHTER HERSENHELFT}

Bij verreweg de meeste mensen is de linker hersenhelft belangtijker voor taal dan de rechter hersenhelft. Toch is ook de rechter hersenhelft voor ons talvermogen niet zonder belang. Mer name voor her begrijpen van connotatieve en metaforische aspecten van betekenis, en voor het interpreteren en aanbrcngen $\operatorname{van}$ (de cmotionele aspecten van) zinsintonatie is een intacte rechter hersenhelft vereist (Hagoort, 1997). Desalniettemin leidt een laesie in de techter hersenhelft dootgaans niet tot ernstige afatische verschijnselen.

In de context van de beperkte rol voor de rechter hersenhelft die op basis van laesiestudies kon worden geconcludeerd, kwam het als een verrassing dat in zeer veel PET-studies niet alleen activatie in de linker hersenhelft zichrbaar was, maar vaak ook in de homologe gebieden in de rechter hersenhelft. Kenne- 
lijk speelt de rechter hersenhelft in her normale proces van taalverwerking een grotere rol dan gedacht. De laesiestudies suggereren echter dat deze bijdrage niet in zijn volledige onvang noodzakelijk is. Toekomstig onderzock zal moeten uitwijzen hoe gebieden in de recturer hersenhelft precies zijn ingeschakeld in het netwetk van caalgebieden in het brein.

\section{$5 \quad$ Conclusie}

Als we ons afvragen welke gebieden in de herscnen taal verwerken, is het antwoord afhankelijk van de vraag over welk aspect van taal we het eigenlijk hebben. Bij de waarneming van geschreven woordvormen zijn andere gebieden betrokken dan bij de waarneming van woordklanken. Wat een woord bete-

- kent, wordt doot een ander circuit van herserigebieden bepaald dan hoe een woord klinkt of geschreven wordt. Kortom, wanneer wij woorden spteken of lezen danwel ernaar luisteren, wordt een groot aantal hersengebieden gerecrulteerd. Deze gebieden zijn onderling met elkaat verbonden, maar ze zijn ook verbonden met de primaire visucle gebieden (lezen) en auditieve gebicden (luisteren), de motorische schors (spreken), en met de hersengebieden die onze aandacht stuten. Aftankelijk van wat de taalgebruiker op een bepaald moment met woorden moet doen, wordt de activiteit van deze verschillende gebieden neuxaal georkestreerd. Uiteraard neemt de complexiteit van dit samenspel in het brein alleen nog maar toe indien we daarbij betrekken hoe woorden in een zinsverband worden ingebed, hoe bij het uitspreken van een zin de juiste intonatie wordt geproduceerd, cnzovoort.

Het onderzoek naar de samenhang tussen taal en hersenen maakt duidelijk dat taal, net als andere hogere cognitieve functies, zowel gelokaliseerd als gedistribueend in her brein verankerd is. Gelokaliseerd in de zin dat bepaalde gebieden in het brein noodzakelijk en verantwootdelijk zijn voot ons taalvermogen; gedistribucerd, omdat de verschillende deelaspecten van dit taalvermogen uitkomst zijn van cen neurofysiologisch proces waarbij verschillende hersengebieden worden ingeschakeld en hun activiteit temporeel op elkatr is afgesteld. 


\section{Fundamenten | Neurale architecruur}

Friston, K.]. [1997). Imaging cognitive anatomy. Trends in Cognitive Sciences, 1, 2 t-27.

Geschwind, N. [1979]. Specializations of the human bsain. Scientifir Americain, 241, 158 - 168.

Hagoort, P. [1997). Valt er nog te lachen zonder de rechter hersenthelft? Pyychologit, 16, 52-53. Hagoort, P., \& Van Turennont, M. (1997). The electrophysiology of speaking Possibilities of event-related pocential research on speech production. Ia: W. Halsejjn, P.H.H.M. van Lieshout, \& H.F.M. Peters (ted.). Speeck prodaction: Moton control, brains research and flucncy fisordcrs. Amsterdar: Elsevier.

Hagoort, P., Brown, C.M., \& Groorhusen, J. (1993). The syntactic positive shifr \{sPs) as an ERP-measure of syntactic processing. Langitageand Cogntive Practsses, 8, 439-483.

Hagoort, $P$, e.a. (19g7). The neural cikcuitiy involved in the xeading of german words and psetadowords. Manustript.

Just, M.A. e.a. (19g6). Brain Acrivation Modulated by Sentence Comprehension. Science, 274 , 214-126.

Kwong, K.K., e.a. [1992). Dynamic magnetic tesonance imaging of human brain activicy during primary sensory stimulation. Proretings of the National Acaidemy of Sciences USA, 89, $5675-5679$.

Lassen, N.A. (1966). The luxury perfusion syndrome and its possible telation to acute tnetabolic acidosis localized within the brain. Lancetz, $1113-1115$.

Lassen, N.A., \& Ingrat, D.H. ( 197 2) Radioisotopic 2ssessment of regional cerebral blood Bows. Progress in Netclear Medkint. VoI. L. Baltimoxt: University Park Ptess.

Liberman, A.M., \& Mattingly, 1.G. (1989). A specialization for speech perceprion. Science, 243, 489-494.

Mazoyer, B.M., c.a. $(1993)$. The cortical representation of speech. fousual of Coynisive Neuroscience, $5,467-479$.

Mesularn, M-M. (1990). Large-scale neurocognirive nezworks and distributed processing for attention, language, and memory, intnals of Neurology, 28, 597-61 3.

Nichelli, P., e.a. (1995). Where the brain appreciates the moral of a story. NeuroReport, 6 . $2309-23 \mathrm{I} 3$.

Ogawa, S., e.a. (1990). Oxygen-setrsitive contrast in magnetic resonance image of rodent brain at high magnetic fields. Masnnetic Fesonance Medicine, 14, 68-78.

Osrerhout, L, \& Holcomb, P.J. (1992). Event-related brain potentials elicited by syntactic anomaly. Journal of Memory and Langieage, 31, 785-806.

PocppeI, D. (1996). A critical review of PET-studies of phonological processing. Brain ard Langange, 55, 317-35t.

Price, C.). Moore, C.)., \& Frtckowiak, R.S.J. (1996a). The effect of varying stimulus rate and duration on brain activiry during reading. Neuroinngt, 3, 40-52.

Price, C.J., Wise, R.].S., \& Ftackowiak, R.S.J. [19966\}. Demonstrating the implicit processing of visualty preseneed words and pseudowords. Cerebral Contex, $6,62-70$.

Pugh, K.R., c.a. [1996). Cercbral organization of componeac processes in reading. Broin, 1 19, $1221-1238$.

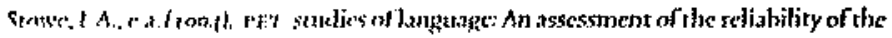

